\title{
Styrene Biofiltration in a Trickle-Bed Reactor
}

\author{
V. Novak ${ }^{1}$, J. Paca ${ }^{1 *}$, M. Halecky ${ }^{1}$ and Carlos Ricardo Soccol ${ }^{2}$, \\ ${ }^{I}$ Institute of Chemical Technology; 16628 Prague - Czech Republic; Vratislav.Novak@vscht.cz; \\ Jan.Paca@vscht.cz. ${ }^{2}$ Universidade Federal do Paraná; Sector de Technologica; 81531-970; Curitiba - PR - Brasil
}

\begin{abstract}
The biological treatment of styrene waste gas in a trickle-bed filter (TBF) was investigated. The bioreactor consisted of a two-part glass cylinder (ID $150 \mathrm{~mm}$ ) filled with $25 \mathrm{~mm}$ polypropylene Pall rings serving as packing material. The bed height was $1 \mathrm{~m}$. Although the laboratory temperature was maintained at $22{ }^{\circ} \mathrm{C}$, the water temperature in the trickle-bed filter was slightly lower (about $18^{\circ} \mathrm{C}$ ). The main aim of our study was to observe the effect of empty-bed residence time (EBRT) on bioreactor performance at a constant pollutant concentration over an extended time period. The bioreactor was inoculated with a mixed microbial consortium isolated from a styrenedegrading biofilter that had been running for the previous two years. After three weeks of acclimation period, the bioreactor was loaded with styrene $\left(100 \mathrm{mg}^{-3} \mathrm{~m}^{-3}\right.$. EBRT was in the range of $53 \mathrm{~s}$ to $13 \mathrm{~s}$. A maximum elimination capacity $(E C)$ of $11.3 g_{C} \cdot m^{-3} \cdot h^{-1}$ was reached at an organic loading $(O L)$ rate of $18.6 g_{C} \cdot \mathrm{m}^{-3} \cdot h^{-1}$.
\end{abstract}

Key words: Biofiltration, styrene, trickle - bed filter, loading by air flow rate

\section{INTRODUCTION}

Styrene is a widely produced aromatic hydrocarbon used in many chemical industries, in particular in the production of polystyrene, butadiene-styrene latex, copolymer resins and rubber (Dehghanzadeh et al. 2005; Jorio et al. 2000a; Lu et al. 2001). Approximately 21 million tones of styrene were consumed worldwide in 2000, a 50\% increase from 1993 (Chung et al. 2006).

Styrene may leak into the environment during any step of the production process, generating, as a result, great amounts of contaminated effluents and off-gases, which, if not properly treated, may have an adverse impact on air quality. Thus styrene has become a serious threat to public health and welfare (Lu et al. 2001). Recently the metabolism of styrene has been extensively studied in mice and rats in order to obtain relevant

*Author for correspondence toxicological data. Several studies reported both hepatotoxic and pneumotoxic effects (Carlson et al. 2006; Harvilchuck and Carlson 2006). Acute exposure to styrene in humans results in mucous membrane and eye irritations, as well as in gastrointestinal disorders. Chronic contact causes a variety of discomforts including headache, weakness, depression, decreased lung ventilation, possible hearing loss, chronic neuropathy and other neurotoxic effects (Dehghanzadeh et al. 2005; Chung et al. 2006; Lawton et al. 2006). Styrene is a colourless, volatile, strong-smelling liquid, the odour of which is obvious at less than $0.5 \mathrm{ppm}$ (Jorio et al. 2000a).

Although higher concentrations of styrene have been observed in urban areas where there is greater industrial activity, occupational exposure to airborne styrene is modest in most parts of the industry $\left(<10 \mathrm{mg} \cdot \mathrm{m}^{-3}\right)$. However it tends to be relatively high $\left(40-400 \mathrm{mg} . \mathrm{m}^{-3}\right)$ in the field of reinforced plastics (Nylander-French et al. 1999). In such fields, the microbial purification of 
contaminated gases has become economically feasible (Pol et al. 1998). Biofiltration is a promising technology for the treatment of large off-gas volumes of diluted styrene emissions in the air (Tresse et al. 2003). Furthermore, it is environmentally friendly, with contaminants fully converted, at low temperatures, into nonhazardous final products (Zilli et al. 2001). Compared with traditional technologies, biofiltration is also a cost-effective solution for the treatment of low-strength (as well as some medium-strength) waste gases produced by volatile organic compounds (VOCs) (Jang et al. 2005; Kim et al. 2005). Additionally, biofiltration does not produce the further emissions common to conventional waste gas treatment technologies such as carbon adsorption, liquid scrubbing, condensation, thermal incineration and catalytic incineration.

These processes have been commonly used for removing VOCs, but the more stringent environmental regulations of recent years have led to the development of innovative, low-cost treatment technologies based on a biological approach, and biofiltration seems to be the answer (Jorio et al. 2000b).

The biofiltration of styrene waste gas has been the subject of a number of studies, both at bench-scale (Dehghanzadeh et al. 2005; Jorio et al. 2000a; Lu et al. 2001) and pilot-plant scale (Webster et al. 1999). The majority of these studies have conducted experiments using biofilters. Few studies involve trickle-bed filters, for which continuous flow of the liquid phase is characteristic. Trickle-bed filters are often thought to be more efficient than biofilters, but the feeding of nutrients stimulates biomass growth. Clogging by excessive biomass accumulation is one of the main obstacles to the implementation of highperformance trickle-bed filtration (Alonso et al. 1997).

In this study we observed the dependency of removal performance on EBRT for a trickle-bed filter. The goal of our study was to achieve the highest possible elimination capacity at different influent loadings, while maintaining satisfactory removal efficiency.

\section{MATERIALS AND METHODS}

\section{Design and operating conditions of bioreactor}

A schematic diagram of the bench-scale tricklebed filter is shown in Fig. 1. The reactor consisted of three cylindrical compartments. The two upper sections were made of tempered glass with total height of $150 \mathrm{~cm}$. The third segment, made of polypropylene, served as a sump for circulating liquid. The sump was separated from the column by a perforated plate. All three sections had an internal diameter of $15 \mathrm{~cm}$. The reactor was packed with polypropylene Pall rings $(25 \times 25 \times 1$ $\mathrm{mm}$ ) up to a bed height of $100 \mathrm{~cm}$. The cylindrical unit and auxiliary appliances [water circulating pump (Micropump, USA), peristaltic pumps, syringe pumps] were placed in a supporting steel construction. The $\mathrm{pH}$ value was set to $7.0 \pm 0.2$ and this level was maintained by the addition of $0.1 \mathrm{M} \mathrm{NaOH}$ solution. A dose of alkaline solution was supplied to the reactor by a peristaltic pump, which, as the reactor had no air humidifier, also had the effect of replenishing the evaporated water content. The trickle-bed filter was operated in upflow counter-current mode. 


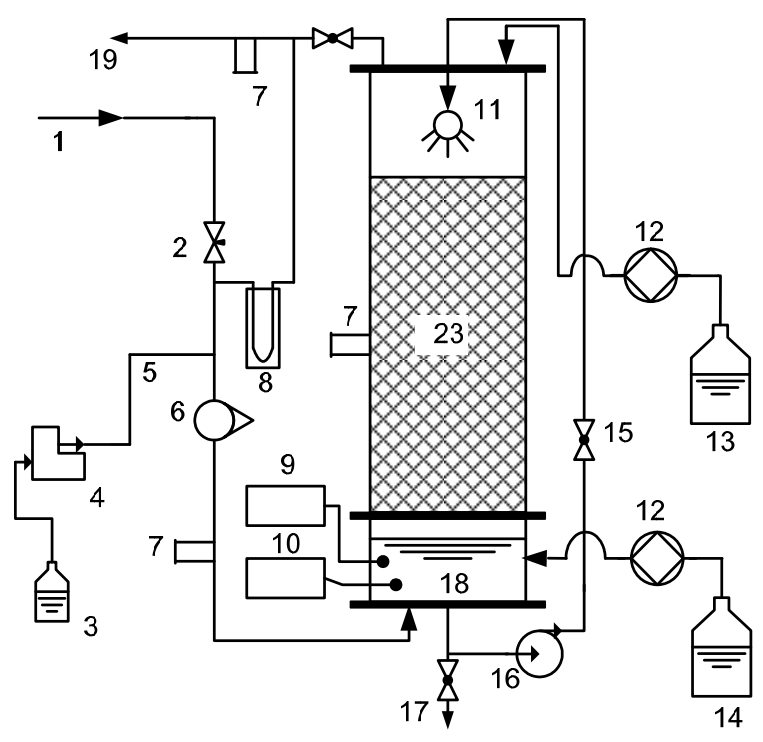

Figure 1 - Schematic diagram of the trickle-bed filter. 1-air inlet, 2-needle valve, 3-pure styren solution, 4-syringe pump, 5-capillary, 6-rotameter, 7-sampling ports, 8-liquid manometer, 9-thermometer, 10-pH-meter, 11-spray nozzle, 12-peristaltic pump, 13nutrient solution tank, 14-sodium hydroxide solution tank, 15-choke valve, 16medium circulating pump, 17-drain valve, 18-drain vessel, 19-outlet gas

\section{Inoculum and culture medium}

The mixed microbial culture for inoculation was taken from a previously running styrene-degrading biofilter. An inoculum preparation was performed in 250-ml Erlenmeyer flasks containing $100 \mathrm{ml}$ of mineral medium at $27-30{ }^{\circ} \mathrm{C}$ on a rotary shaker. After $96 \mathrm{~h}$ of fed batch cultivation the cells wereharvested, centrifuged and then re-suspended in fresh nutrient medium for use as an inoculum in the biodegradation experiments. The cultivation and degradation media have the following composition: $\left(\mathrm{g} . \mathrm{L}^{-1}\right) \quad\left(\mathrm{NH}_{4}\right)_{2} \mathrm{SO}_{4} \quad[2.00] ; \mathrm{KNO}_{3}$ [1.00]; $\mathrm{K}_{2} \mathrm{HPO}_{4} \quad$ [4.30]; $\mathrm{KH}_{2} \mathrm{PO}_{4} \quad$ [3.40]; $\mathrm{MgCl}_{2} \cdot 6 \mathrm{H}_{2} \mathrm{O}$ [0.34]. Trace elements feed composition ( $\mu \mathrm{g} / \mathrm{L})$ : $\mathrm{FeSO}_{4} .7 \mathrm{H}_{2} \mathrm{O}$ [0.16]; $\mathrm{ZnSO}_{4} .7$ $\mathrm{H}_{2} \mathrm{O}$ [0.30]; $\mathrm{MnSO}_{4} . \mathrm{H}_{2} \mathrm{O}$ [0.10]; $\mathrm{CuSO}_{4} .5 \mathrm{H}_{2} \mathrm{O}$ [0.10]; $\mathrm{Na}_{2} \mathrm{MoO}_{4}$. $2 \mathrm{H}_{2} \mathrm{O}$ [0.10]; $\mathrm{CaSO}_{4}$. $0.5 \mathrm{H}_{2} \mathrm{O}$ [0.15]; $\mathrm{CoSO}_{4} .7 \mathrm{H}_{2} \mathrm{O}$ [0.10]; $\mathrm{Na}_{2} \mathrm{~B}_{4} \mathrm{O}_{7} .10 \mathrm{H}_{2} \mathrm{O}$ [0.10].

\section{Pollutant supply}

The styrene used in this study was a monomer species; $99 \%$ reagent purity grade, inhibited with $0.005 \%$ of 4-tert-butylcatechol (Sigma-Aldrich Chemie, Germany). To generate an air stream contaminated with styrene vapors, the flow of compressed air was forced through a glass T-pipe, at which a pollutant injection point was situated.
A syringe pump (Gilson, France) ensured a continuous feed of styrene.

\section{Analytical methods}

Styrene in the influent and effluent gas was determined by GC analysis. Gaseous samples were collected from each of the sampling ports using $500-\mu \mathrm{L}$ gastight syringes (Hamilton, USA). The gas chromatograph (Hewlett Packard 6890 Series, California, USA) was equipped with a flame ionization detector (FID). A 30 m HP INNOWAX crosslinked polyethyleneglycol capillary column (0.53mm i.d.; $1 \mu \mathrm{m}$ film thickness) was used for the experiment. GC analytical conditions were as follows: injection and detection temperatures were 250 and $300{ }^{\circ} \mathrm{C}$, respectively, oven temperature was $150{ }^{\circ} \mathrm{C}$, and flow of argon as a carrier gas was $6.3 \mathrm{ml} / \mathrm{min}$. Under these conditions the styrene retention time was $1.9 \mathrm{~min}$.

\section{Evaluation parameters}

The parameters studied were calculated from the following equations: 


$$
\begin{aligned}
& O L=\frac{c_{\text {in }} \cdot V_{g}}{H \cdot S}, \quad E C=\frac{\left(c_{\text {in }}-c_{\text {out }}\right) \cdot V_{g}}{H \cdot S}, \\
& E B R T=3600 \cdot \frac{V_{B}}{V_{g}}, \quad R E=\frac{E C}{O L} \cdot 100
\end{aligned}
$$

where $O L$ is the organic load on the reactor's empty bed volume $\left(\mathrm{g} \cdot \mathrm{m}^{-3} \cdot \mathrm{h}^{-1}\right), C_{\text {in }}$ and $C_{\text {out }}$ are the inlet and outlet pollutant concentrations respectively $\left(\mathrm{g} \cdot \mathrm{m}^{-3}\right), V_{g}$ is the air flow rate $\left(\mathrm{m}^{3} \cdot \mathrm{h}^{-1}\right)$, $\mathrm{V}_{\mathrm{B}}$ is the filter bed volume, $H$ is the bed height (m), $S$ is the area of the cross section of the reactor $\left(\mathrm{m}^{2}\right), E C$ is the elimination capacity $\left(\mathrm{g} \cdot \mathrm{m}^{-3} \cdot \mathrm{h}^{-1}\right)$, and $R E$ is the removal efficiency $(\%)$.

\section{Temperature settings}

The experiment was carried out in an airconditioned laboratory in order to maintain isothermal conditions of $22^{\circ} \mathrm{C}$. However the water temperature in the trickle-bed filter was slightly lower (about $18^{\circ} \mathrm{C}$ ).

\section{RESULTS AND DISCUSSION}

After three weeks of acclimation period the experiment has been started. The loading test consisted of reducing the EBRT from $53 \mathrm{~s}$ to $13 \mathrm{~s}$ in several discrete steps. These correspond to the air flowrate of 20, 30, 40, 50, 60, 70 and 80 L.min 1 . The styrene inlet concentration was maintained at $100 \mathrm{mg} \cdot \mathrm{m}^{-3}$ for the whole experiment runtime. Figure 2 displays the overall performance of the reactor over time. Each step lasted 10 days in average. Steps of such length were required to achieve steady state conditions at the very beginning of the experiment. Stable removal performance was reached after 25 days of operation. Despite changes to the EBRT, during the period from day 20 to 54 the elimination capacity showed no significant variation (9.3-11.3 $\left.\mathrm{g}_{\mathrm{C}} \cdot \mathrm{m}^{-3} \cdot \mathrm{h}^{-1}\right)$. The reactor, therefore, was not responding to progressive loading. Removal performance dropped off (down to approximately $30 \%$ ) with each increase in the gas flow rate. The trickle-bed filter handled loads up to $10-15 \mathrm{~g}_{\mathrm{C}} \cdot \mathrm{m}^{-}$ ${ }^{3} \cdot \mathrm{h}^{-1}$ with a relatively high rate of removal, but greater loadings were only partially degraded. Our filtration results are comparable with those of Choi et al. (2004), who reported an average removal rate of $13.3 \mathrm{~g}_{\mathrm{C}} \cdot \mathrm{m}^{-3} \cdot \mathrm{h}^{-1}$ in a pilot-scale trickle-bed filter with an organic load of $20.6 \mathrm{~g}_{\mathrm{C}} \cdot \mathrm{m}^{-3} \cdot \mathrm{h}^{-1}$ after 5 months of operation.

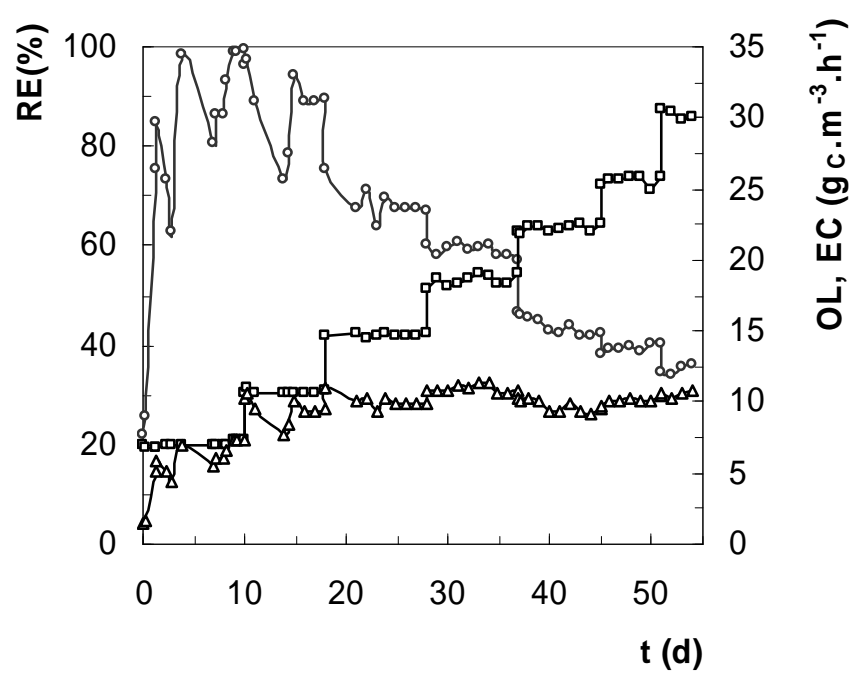

Figure 2 - TBF performance characteristics, RE: ○, OL: $\square, \mathrm{EC}$ :

The results from the loading tests are shown in Fig. 3. The reactor worked satisfactorily up to an organic load of $10 \mathrm{~g}_{\mathrm{C}} \cdot \mathrm{m}^{-3} \cdot \mathrm{h}^{-1}$. From that point, however, pollutant breakthrough occurred. Consequently the elimination capacity began to drop from $100 \%$ removal, and for the rest of the experiment remained almost unchanged. The trickle-bed filter was operated at its maximum elimination capacity. Such operating conditions were interpreted by Cox and Deshusses (2002) as 
a zero order regime. A similar trend was also observed by Ottengraf et al. (1986), who suggested that it was the result of a low styrene inlet concentration leading to diffusion limitation in the biolayer. Cox et al. (1997) confirmed this hypothesis, identifying the critical pollutant concentration at the transition point of reaction to diffusion limitation as approximately $60 \mathrm{mg} \cdot \mathrm{m}^{-3}$.

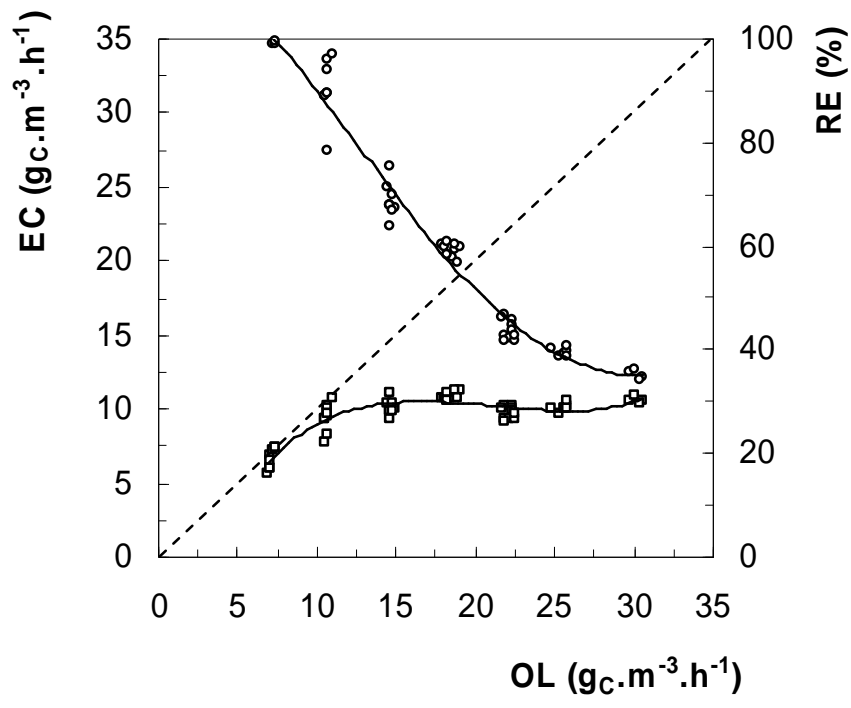

Figure 3 - Elimination capacity and removal efficiency as a function of loading. RE/EC: (०)/( $\square)$

\section{CONCLUSIONS}

The results of this study suggest that styrene degradation in the laboratory trickle-bed filter was strongly dependent on the EBRT. The reactor displayed satisfactory styrene removal performance at lower EBRTs of approximately $35 \mathrm{~s}$ and more. Therefore our results show the significant potential applicability of trickle-bed filters for the handling of high flow rates of waste gas streams containing low concentrations of styrene.

\section{ACKNOWLEDGEMENTS}

The work was financially supported by the Ministry of Education of the Czech Rep., Project MSM 60446137305.

\section{REFERENCES}

Alonso C., Suidan M. T., Sorial G. A., Smith F. L., Biswas P., Smith P. J., Brenner R. C. (1997), Gas Treatment in Trickle-Bed Biofilters: Biomass, How Much Is Enough? Biotechnology and Bioengineering. 54, 583-594.
Carlson G. P., Turner M., Mantick N. A. (2006), Effects of styrene and styrene oxide on glutathionerelated antioxidant enzymes. Toxicology. 227, 217226.

Cox H. H. J., Deshusses M. A. 2002. Biotrickling Filters for Air Pollution Control. In: Bitton G, editor. The Encyclopedia of Environmental Microbiology: J. Wiley and Sons. p 782-795.

Cox H. H. J., Moerman R. E., Van Baalen S., Van Heiningen W. N. M., Doddema H. J., Harder W. (1997), Performance of a Styrene-Degrading Biofilter Containing the Yeast Exophiala jeanselmei. Biotechnology and Bioengineering. 53, 259-266.

Dehghanzadeh R., Torkian A., Bina B., Poormoghaddas H., Kalantary A. (2005), Biodegradation of styrene laden waste gas stream using a compost-based biofilter. Chemosphere. 60, 434-439.

Harvilchuck J. A., Carlson G. P. (2006), Comparison of styrene and its metabolites styrene oxide and 4vinylphenol on cytotoxicity and glutathione depletion in Clara cells of mice and rats. Toxicology. 227, 165-172.

Choi D.-S., Devinny J. S., Deshusses M. A. (2004), Bacterial degradation of styrene in waste gases using a peat filter. Journal of Environmental Engineering. 130, 322-328. 
Chung J.-K., Yuan W., Guangxian L., Zheng J. (2006), Investigation of bioactivation and toxicity of styrene in CYP2E1 transgenic cells. Toxicology. 226, 99-106.

Jang J. H., Hirai M., Shoda M. (2005), Performance of a Styrene-Degrading Biofilter Inoculated with Pseudomonas sp. SR-5. Journal of Bioscience and Bioengineering. 100, 297-302.

Jorio H., Bibeau L., Heitz M. (2000a), Biofiltration of Air Contaminated by Styrene-Effect of Nitrogen Supply, Gas Flow Rate, and Inlet Concentration. Environmental Science and Technology. 34, 17641771.

Jorio H., Bibeau L., Heitz M., Viel G. (2000b), Effects of gas flow rate and inlet concentration on xylene vapors biofiltration performance. Chemical Engineering Journal. 76, 209-221.

Kim D., Cai Z., Sorial G. A. (2005), Evalution of trickle-bed air biofilter performance under periodic stressed operating conditions as a function of styrene loading. Jornal of Air and Waste Managment Association. 55, 200-209.

Lawton B. W., Hoffmann J., Triebig G. (2006), The ototoxicity of styrene: a review of occupational investigations. International Archives of Occupational and Environmental Health. 79, 93102.

Lu C., Lin M.-R., Lin J. (2001), Removal of styrene vapor from waste gases by a trickle-bed air biofilter. Journal of Hazardous Materials. B82, 233-245.
Nylander-French L. A., Kupper L. L., Rappaport S. M. (1999), An Investigation of Factors Contributing to Styrene and Styrene-7,8-oxide Exposures in the Reinforced-Plastics Industry. The Annals of Occupational Hygiene. 43, 99-105.

Ottengraf S. P. P., Meesters J. J. P., Van Den Oever A. H. C., Rozema H. R. (1986), Biological elimination of volatile xenobiotic compounds in biofilters. Bioprocess Engineering. 1, 61-69.

Pol A., Van Haren F. J. J., Op Den Camp H. J. M., Van Der Drift C. (1998), Styrene removal from waste gas with a bacterial biotrickling filter. Biotechnology Letters. 20, 407-410.

Tresse O., Lescob S., Rho D. (2003), Dynamics of living and dead bacterial cells within a mixedspecies biofilm during toluene degradation in a biotrickling filter. Journal of Applied Microbiology. 94, 849-855.

Webster T. S., Cox H. H. J., Deshusses M. A. (1999), Resolving operational and performance problems encountered in the use of a pilot/full-scale biotrickling filter reactor. Environmental Progress. 18, 162-172.

Zilli M., Palazzi E., Sene L., Converti A., Del Borghi M. (2001), Toluene and styrene removal from air in biofilters. Process Biochemistry. 37, 423-429.

Received: November 28, 2006; Revised: February 07, 2007; Accepted: August 24, 2007. 